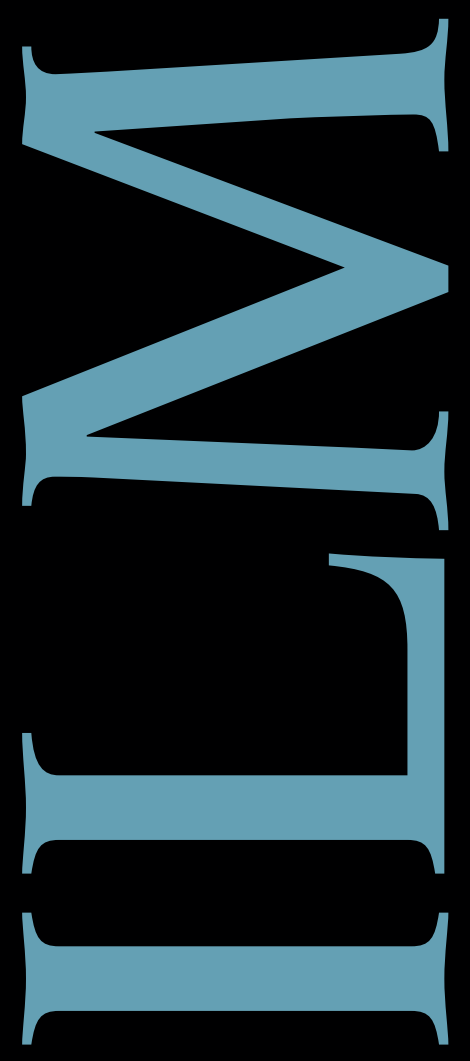

\title{
International
}

Legal

Materials

\section{INSIDE THIS ISSUE}

- Abu Zubaydah v. Lithuania (Eur. Ct. H.R.) Introductory Note by Christina M. Cerna

- MP v. Secretary of State for the Home Department (CJEU) Introductory Note by Anne Aagten

- United Nations Security Council Resolution 2379 Introductory Note by Scott A. Gilmore 


\section{INTERNATIONAL LEGAL MATERIALS ${ }^{\text {}}$}

\section{Foreword}

From its inception, the collection, publication, and dissemination of important international legal materials has been among the primary functions of the American Society of International Law. These materials were originally published as a section of the American Journal of International Law, and for the past 50 years they have been produced as a freestanding publication. Throughout this period, International Legal Materials has filled a critical need by giving scholars and practitioners access to primary source materials that were often difficult to find.

Today, with the advent of the Internet, many of these materials are widely available. But the explosion of online information related to international law has made it impossible for busy international lawyers to sift through the vast array of documents and identify those that are truly significant. Happily our editorial staff, working with our Editorial Advisory Committee, devotes the time and expertise to selecting the most significant materials and highlighting them in International Legal Materials and our blog, International Law in Brief. In addition, the Society's ASIL Insights series provides analyses of particularly high-profile developments.

Beginning in 2007, we have introduced all documents published in International Legal Materials with a prefatory note by experts from among our membership. These notes provide summaries of the documents and offer insight into their significance. In this volume, we feature notes by Christina M. Cerna, Anne Aagten, and Scott A. Gilmore. We are extremely grateful to these authors, and we are confident that you will find their contributions of value.

We invite your comments and suggestions as we continue our efforts to meet the evolving needs of the international legal community.

Sincerely,

Mark David Agrast

Chair

Editorial Advisory Committee

International Legal Materials 


\section{STATEMENT OF EDITORIAL POLICY}

International Legal Materials (ILM) is a core publication of the American Society of International Law that reproduces texts of documents reflecting the broad scope and evolution of international law. The range of covered subjects has expanded from traditional topics such as international organizations, jurisdiction, and international trade to include developments in fields such as intellectual property, environmental law, nuclear non-proliferation, human rights, and international criminal law.

ILM serves as both a bi-monthly information service and a widely recognized archive of international law documents for a diverse, global community of legal scholars, government officials, private practitioners, and institutions with a common interest in international law. To meet the varied demands of such a readership, documents are selected from world-wide sources on the basis of their present and future legal significance.

$I L M$ is prepared for publication in Washington, D.C., with both the advice of an Editorial Advisory Committee and the assistance of Corresponding Editors around the world. In order to reproduce texts of selected documents under tight production schedules, the best available source is used, whether electronic or printed.

Readers are invited to send comments to:

Caitlin Behles

Attorney-Editor

International Legal Materials

2223 Massachusetts Avenue, NW

Washington, DC 20008-2864

Telephone: (202) 939-6012

cbehles@asil.org

\section{THE AMERICAN SOCIETY OF INTERNATIONAL LAW}

The American Society of International Law (ASIL) is a nonprofit, nonpartisan, educational membership organization founded in 1906 by U.S. Secretary of State Elihu Root and chartered by Congress in 1950. Headquartered in Washington, D.C., its mission is "to foster the study of international law and to promote the establishment and maintenance of international relations on the basis of law and justice." ASIL holds Special Consultative Status with the Economic and Social Council of the United Nations and is a constituent society of the American Council of Learned Societies.

ASIL's nearly four thousand members hail from more than one hundred nations with nearly 40 percent residing outside the United States. Its members include scholars, jurists, practitioners, government officials, leaders in international and nongovernmental organizations, students, and others interested in international law. Through its many publications, conferences, briefings, and educational events, ASIL seeks to serve the needs of its diverse membership and to advance understanding of international law among policymakers and the public.

ASIL is a volunteer-led organization governed by a sixty-member Executive Council elected by its membership. In partnership with the elected leadership, ASIL is led by an executive director and supported by a professional staff.

\section{Become a Member}

asil.org/membership

Join one of the Society's Partner Programs and Receive Complimentary Ad Space in ILM asil.org/financial-support/sponsors-and-institutional-supporters

Follow the Society on Twitter

twitter.com/asilorg

Like us on Facebook

facebook.com/AmericanSocietyofInternationalLaw 


\section{JOURNAL INFORMATION}

ILM is published six times a year, every other month, in print and online by Cambridge University Press on behalf of the American Society of International Law. To reduce time between acceptance and publication, contributions may appear online as FirstView publications in advance of their scheduled publication in an issue. Discover the entire ILM back archive at cambridge.org/core/journals/international-legal-materials/all-issues.

\section{Subscriptions}

The electronic version of ILM is available to all members of the American Society of International Law by logging in to the ASIL website www.asil.org. Print copies are available to members for an additional fee. To subscribe as a nonmember or recommend a subscription to your librarian go to cambridge.org/core/journals/international-legal-materials/ subscribe.

\section{Submission of Material}

Primary material included in each issue of ILM is carefully chosen by the ILM Editorial Advisory Committee. Authors are solicited to write an Introductory Note to preface each document. The ILM editorial office welcomes efforts to bring suitable primary material to their attention. Those submitting material will be notified of the acceptance of their document for publication. Full instructions on how to submit primary material can be found at cambridge.org/core/journals/international-legal-materials/information/instructions-contributors

\section{Claims and Address Updates}

subscriptions_newyork@cambridge.org (in the USA, Canada and Mexico)

journals@cambridge.org (elsewhere)

\section{Copyright and Permissions}

cambridge.org/about-us/rights-permissions

To Advertise in $I L M$

ad_sales@cambridge.org

Abstracting and Indexing Services

cambridge.org/core/journals/international-legal-materials/information/abstracting-indexing-services

\section{For Other ASIL Publications}

www.asil.org

Proper Citation

ILM shall be cited according to the following example:

57 ILM 12 (2018)

\section{International Law in Brief}

The Attorney-Editor of International Legal Materials also publishes the blog International Law in Brief, which contains objective abstracts of recently released documents pertinent to international law. Documents abstracted in International Law in Brief are later considered for reproduction in ILM. To view International Law in Brief, please visit www.asil.org/blogs/ilib.

ISSN: 0020-7829

E-ISSN: $1930-6571$

(C) American Society of International Law 


\section{Attorney-Editor}

Caitlin Behles

\section{Editorial Advisory Committee}

\author{
Mark Agrast, Chair \\ Roland Adjovi \\ Lee Caplan \\ Christina M. Cerna \\ Jonathan Hafetz
}

\author{
Nancy L. Perkins \\ David Sullivan \\ Allyn Taylor \\ Mairée Uran Bidegain \\ Jeremy M. Weinberg
}

\author{
Lewis Yelin \\ Bruce Zagaris \\ Nassib G. Ziade \\ Members Emeriti \\ John L. Hargrove
}

\section{ILM Corresponding Editors}

Philip C. Aka (Int'l Hum. Rts. L.)

Don Anton (Int'l Env. L., LOS)

Valentina Azarov (Int'l Humanitarian L.)

Paolo Bargiacchi (EU)

Lisl Andrea Brunner (Int'1 Hum. Rts. L.)

Gian Luca Burci (Int'l Health L.)

Kathleen Claussen (Pub. Int'l L., Int'l Arb.)

Alison Dundes Renteln (Pub. Int'l L.)

Richard I. Fine (Int'1 L., Anti-Corruption)

Sarah A. Freuden (Int'l Crim. L., Int'l Hum. Rts. L.)

Maria Gavouneli (LOS)

Thomas D. Grant (Pub. Int'1 L.)

Kevin R. Gray (Int'1 Trade, Int'l Env. L.)

Eckhard Hellbeck (Int'l Disp. Res., Pub. Int'l L.)

Jean-Marie Henckaerts (Int'l Humanitarian L.)

Maria Angela Jardim de Santa Cruz Oliveira (Brazil)

Scott T. Johnson (Int'l Crim. L., Extradition)

Jorge Kamine (Int'1 Inv. and Fin.)

Nathaniel Khng (Int'1 Inv. Arb.)

Theodore P. Kill (Int'l Disp. Res.)

Kenneth Klein (Int'1 Tax'n)

Riikka Koskenma“ki (Pub. Int'l L., Int'l Orgs.)

Artur Kozlowski (Pub. Int'l L.)

Yaraslau Kryvoi (Int'l Arb., Russia)
Vicheka Lay (Int'l Inv.)

Ben Love (Pub. Int'l L., Int'l Arb.)

Julie B. Martin (Int'l Crim. L., Int'l Hum. Rts. L.)

Hilly Moodrick-Even Khen (Int'1 Humanitarian L., Int'l Hum. Rts. L.)

Jason Morgan-Foster (ICJ, Int'1 Hum. Rts. L.)

Boldizsár Nagy (Int'l Refugee L.)

Marko S. Novakovic (Int'l Admin. L.)

Erin Louise Palmer (Int'l Hum. Rts. L.)

Jason Scott Palmer (Int'l Litig., Int'l Arb.)

John R. Pate (Latin Am. Orgs.)

Rafael A. Porrata-Doria (EU, Int'l Com. L.)

Heiko Recktenwald (Int'l Humanitarian L.)

Gustavo Ribeiro (Int'l Econ. L.)

Christopher M. Ryan (Int'l Arb., Int'l Inv. L.)

Jeremy K. Sharpe (Int'l. Disp. Res., Pub. Int'l L.)

William Slomanson (Pub. Int'1 L.)

Frédéric G. Sourgens (Int'1 Disp. Resol.)

Tom Syring (Int'l Humanitarian L., Int'l Refugee L.)

Patricia Cassar Torregiani (LOS, Maritime Sec.)

Anatoly Vlasov (Int'l Crim. L., Int'l Hum. Rts. L.)

Rebecca M. Wallace (Int'l Hum. Rts. L., Int'l Refugee L.)

Todd Weiler (Int'l Econ. L., Int'l Arb.)

Simon N.M. Young (Int'l Hum. Rts. L.) 


\section{INTERNATIONAL LEGAL MATERIALS}

Vol. 57

No. 5

- Contents -

Abu Zubaydah v. Lithuania (Eur. Ct. H.R.)

Introductory Note by Christina M. Cerna

715

MP v. Secretary of State for the Home Department (CJEU)

Introductory Note by Anne Aagten

United Nations Security Council Resolution 2379

Introductory Note by Scott A. Gilmore

BRIEFLY NOTED 